\title{
Carbon emissions as impact of mangrove degradation: A case study on the Air Telang Protected Forest, South Sumatra, Indonesia (2000-2020)
}

\author{
SYAIFUL EDDY ${ }^{1}$, NORIL MILANTARA ${ }^{2}$, MOHAMMAD BASYUNI ${ }^{3, \bullet}$ \\ ${ }^{1}$ Department of Biology, Faculty of Natural Sciences and Technology, Universitas PGRI Palembang. J1. Jend. A. Yani, 9/10 Ulu, Palembang 30251, \\ South Sumatra, Indonesia \\ ${ }^{2}$ Faculty of Forestry, Universitas Muhammadiyah Sumatera Barat. J1. Pasir Kandang No. 4, Koto Tangah, Padang 25172, West Sumatra, Indonesia \\ ${ }^{3}$ Department of Forestry, Faculty of Forestry, Universitas Sumatera Utara. Jl. Tri Dharma Ujung No. 1, Medan 20155, North Sumatra, Indonesia. \\ Tel./fax: +62-61-8201920, `email: m.basyuni@usu.ac.id
}

Manuscript received: 27 February 2021. Revision accepted: 31 March 2021.

\begin{abstract}
Eddy S, Milantara N, Basyuni M. 2021. Carbon emissions as impact of mangrove degradation: A case study on the Air Telang Protected Forest, South Sumatra, Indonesia (2000-2020). Biodiversitas 22: 2142-2149. Massive degradation in ATPF occurs due to anthropogenic activities that have converted this area into a coconut plantation, fishpond, settlement, and agriculture. The purpose of this study was to describe changes in land cover and the amount of $\mathrm{CO}_{2}$ emission in ATPF and its causes during the 2000-2020 period using remote sensing data. Data from remote sensing were used to obtain area, classification and land cover change in each period; meanwhile, carbon stock, emissions, and $\mathrm{CO}_{2}$ sequestration were obtained from the analysis using LUMENS software. The results showed that the emissions resulting from land conversion in ATPF during the 2000-2020 period were much greater than sequestration. Net emissions of 1,928,076.56 tons of $\mathrm{CO}_{2}$-eq with an annual emission rate of 96,403.83 tons of $\mathrm{CO}_{2}$-eq/year. The largest source of emissions came from the conversion of primary forest, coconut plantation and secondary forest to open areas; while the source of sequestration comes from the formation of primary and secondary forests. There need to be restoration and conservation efforts in this area by the government and the community to restore the function of ATPF as a coastal protection forest. This research is the first study to examine land cover changes in mangrove forests using data analysis methods with LUMENS.
\end{abstract}

Keywords: Air Telang Protected Forest, carbon emission, mangrove forest degradation, remote sensing

Abbreviations: ATPF: Air Telang Protected Forest. LUMENS: using Land Use Planning for Multiple Environmental Services

\section{INTRODUCTION}

Mangrove forests grow along the muddy coasts that undulate weakly around the mouths of large rivers and deltas in the intertidal regions of tropical and subtropical countries. Mangrove plant species have different levels of tolerance to salinity and are strongly influenced by geophysical, geographic, geological, hydrographic, biogeographic, climatic and edaphic factors spatially and temporally (Ellison 2002; Linares et al. 2007; Feller et al. 2010; Basyuni et al. 2019, 2014). They provide a variety of environmental services for life and can reduce the impact of global climate change from their ability to store carbon stocks (Lee et al. 2006; Fatoyinbo et al. 2008; Nagelkerken et al. 2008; Koch et al. 2009; Mukherjee et al. 2014; Eddy et al. 2016; Atwood et al. 2017; Ouyang et al. 2018; Hochard et al. 2019; Kusmana et al. 2019). They store up to three times more carbon than inland tropical forests and five times more than upland forests (Donato et al. 2011; Murdiyarso et al. 2015). On the other hand, the reduced quality and quantity of mangrove forests will increase the rate of greenhouse gas emissions in nature, which in turn creates problems in mangrove forest conservation, especially in the context of climate change (Mai et al. 2019).
Air Telang Protected Forest (ATPF) is one of the mangrove protected forests in South Sumatra Province, Indonesia. This protected forest has an area of approximately 12,660.87 ha. Degradation that occurs due to anthropogenic activities such as coconut and oil palm plantations, fishponds, agricultural land, ports, and settlements in this area has resulted in decreased species diversity in it (Eddy et al. 2017, 2019, 2021). One of the indicators of disturbed ATPF mangrove forest is Nypa fruticans invasion in almost all zones, from tidal zone to near land zone (Eddy and Basyuni 2020). Recently it has been reported that one of the anthropogenic drivers of mangrove loss in ATPF was coconut plantation (Eddy et al. 2021).

This study describes changes in land cover and the amount of $\mathrm{CO}_{2}$ emissions in ATPF and their causes during the 2000-2020 period. Data obtained through remote sensing to determine land cover changes that have occurred. In addition, the determination of carbon stocks and $\mathrm{CO}_{2}$ emissions and sequestration were determined using Land Use Planning for Multiple Environmental Services (LUMENS) software (van Noordwijk et al. 2016). This software can help analyze carbon emissions by entering data on changes in land cover over a certain period in an area (Nguyen et al. 2016; Untari et al. 2018; Do et al. 2020). The results of this analysis are expected to be a 
reference for the government in determining policies to reduce carbon emissions as one of the efforts to mitigate global climate change.

\section{MATERIALS AND METHODS}

\section{Study area}

Air Telang Protected Forest (ATPF) is a mangrove forest with an area of approximately $12,660.87$ ha which is directly adjacent to the east with Banyuasin II and Muara Telang Districts; in the west by the Banyuasin River; in the north by the Bangka Strait; and in the south with Muara Telang District. Many communities and companies have converted this protected forest into coconut plantations, oil palm plantations and fishponds. Plants in this region are dominated by Nypa fruticans for the tree level, Rhizophora apiculata for saplings and Acrostichum aureum for understorey/seedling levels (Eddy et al. 2019).

\section{Methodology}

The data used in this study are spatial data of land cover in 2000 and 2020 in the form of raster data and administrative data in the form of vector data. The supporting data used are the reference map of land use types and the carbon density reference tabular data for each land cover type. Land cover data was obtained based on the results of remote sensing data from Landsat imagery for 2000 and 2020 with specs obtained from USGS glovis (Table 1). We used Landsat 5 TM data types in 2000 and Sentinel-2 in 2020. Although there are differences in spatial resolution between the two, we have minimized errors through our supervised classification method. In addition, we also used Landsat 8 imagery data to adjust and correct the land cover type generated from the Sentinel-2 imagery in 2020. Forestry thematic maps and relevant land cover maps obtained from the South Sumatra Provincial Forestry Service are also used to support land cover classification and to improve the accuracy of classification results.

Land cover data were analyzed using a Geographic Information System (GIS) using ArcGIS 10.5 software. Land cover classification based on land use type and tree canopy cover density. The land cover type classification consists of primary forest, secondary forest, coconut plantation, open area, fishpond and water body. Several field survey locations were determined using the Geographical Positioning System (GPS). The field survey points we used (Table 2) were the same as those we used in our previous research (Eddy et al. 2021).
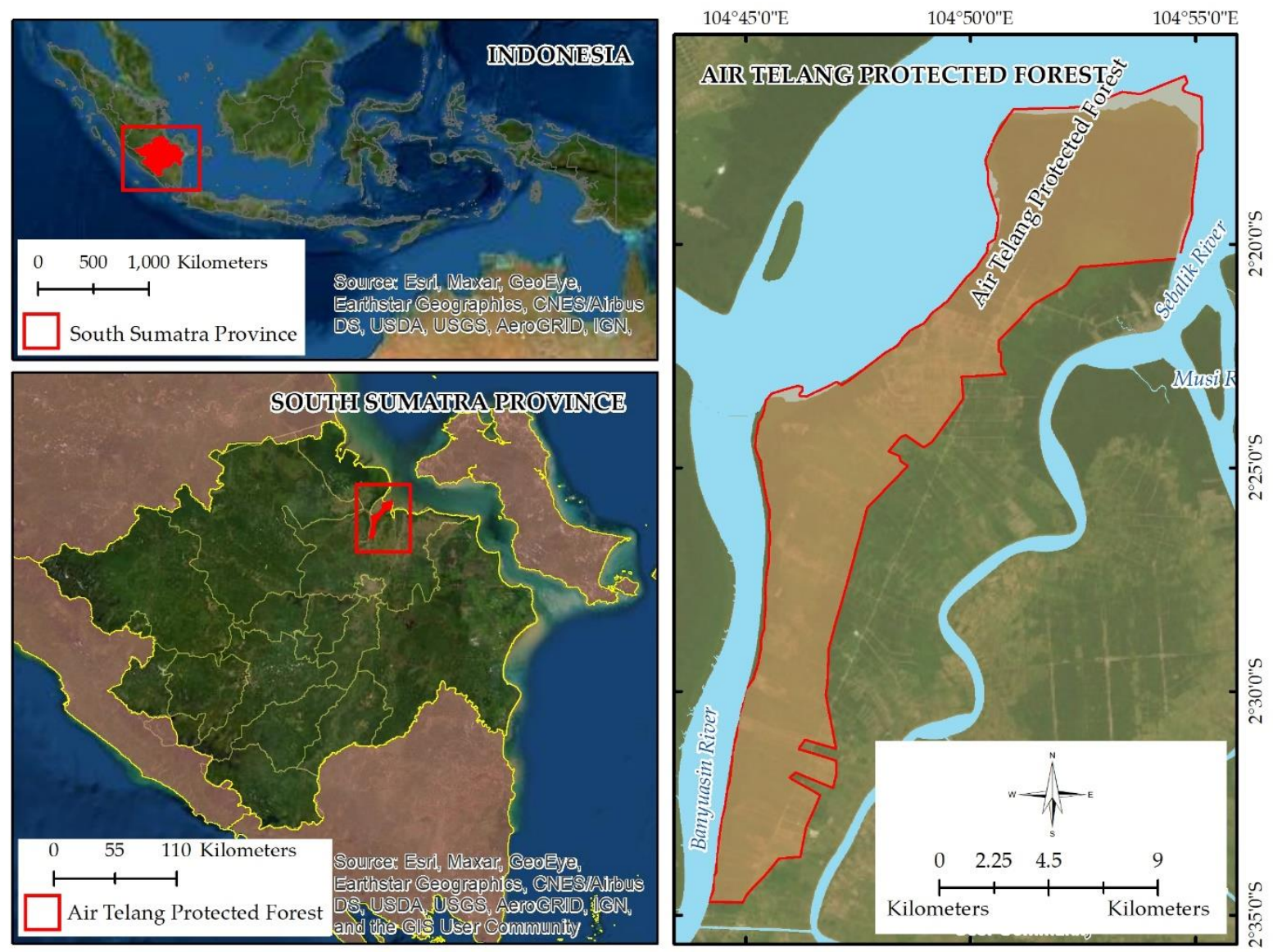

Figure 1. Map of ATPF locations in South Sumatra Province, Indonesia. Map coordinate system: UTM projection, zone 48 S, datum WGS 1984 
Table 1. Specifications of Landsat Image data used

\begin{tabular}{lcccc}
\hline \multicolumn{1}{c}{ Data type } & $\begin{array}{c}\text { Bands } \\
\text { kind }\end{array}$ & $\begin{array}{c}\text { Resolution } \\
(\mathbf{m})\end{array}$ & $\begin{array}{c}\text { Date of } \\
\text { acquisition }\end{array}$ & Source \\
\hline Landsat 5 TM RGB 543 250 & $19-08-2000$ & USGS Glovis \\
Sentinel-2 & RGB 654 250 & 20-04-2020 & USGS Glovis \\
\hline
\end{tabular}

Table 2. The coordinates of the field survey results using a Geographical Positioning System (GPS) (Eddy et al. 2021)

\begin{tabular}{|c|c|c|c|}
\hline No & Latitude & Longitude & Actual_con \\
\hline 1 & $2^{\circ} 32^{\prime} 0.874 " \mathrm{~S}$ & $104^{\circ} 45^{\prime} 52.912^{\prime \prime} \mathrm{E}$ & Secondary forest \\
\hline 2 & $2^{\circ} 16^{\prime} 42.162^{\prime \prime} \mathrm{S}$ & $104^{\circ} 54^{\prime} 22.317^{\prime \prime} \mathrm{E}$ & Secondary forest \\
\hline 3 & $2^{\circ} 20^{\prime} 36.549^{\prime \prime} \mathrm{S}$ & $104^{\circ} 51^{\prime} 36.003^{\prime \prime} \mathrm{E}$ & Secondary forest \\
\hline 4 & $2^{\circ} 22^{\prime} 31.778^{\prime \prime} \mathrm{S}$ & $104^{\circ} 48^{\prime} 15.035^{\prime \prime} \mathrm{E}$ & Primary forest \\
\hline 5 & $2^{\circ} 17^{\prime} 20.364^{\prime \prime} \mathrm{S}$ & $104^{\circ} 52^{\prime} 15.878^{\prime \prime} \mathrm{E}$ & Primary forest \\
\hline 6 & $2^{\circ} 19^{\prime} 55.811 " \mathrm{~S}$ & $104^{\circ} 50^{\prime} 45.469^{\prime \prime} \mathrm{E}$ & Primary forest \\
\hline 7 & $2^{\circ} 33^{\prime} 15.545^{\prime \prime} \mathrm{S}$ & $104^{\circ} 45^{\prime} 39.05^{\prime \prime} \mathrm{E}$ & Coconut plantation \\
\hline 8 & $2^{\circ} 24^{\prime} 21.234^{\prime \prime} \mathrm{S}$ & $104^{\circ} 48^{\prime} 54.87^{\prime \prime} \mathrm{E}$ & Coconut plantation \\
\hline 9 & $2^{\circ} 31^{\prime} 0.584^{\prime \prime} \mathrm{S}$ & $104^{\circ} 45^{\prime} 58.816^{\prime \prime} \mathrm{E}$ & Coconut plantation \\
\hline 10 & $2^{\circ} 23^{\prime} 23.353^{\prime \prime} \mathrm{S}$ & $104^{\circ} 48^{\prime} 21.203^{\prime \prime} \mathrm{E}$ & Fishpond \\
\hline 11 & $2^{\circ} 21^{\prime} 59.763 " \mathrm{~S}$ & $104^{\circ} 50^{\prime} 28.207^{\prime \prime} \mathrm{E}$ & Fishpond \\
\hline 12 & $2^{\circ} 23^{\prime} 35.178^{\prime \prime} \mathrm{S}$ & $104^{\circ} 47^{\prime} 53.384^{\prime \prime} \mathrm{E}$ & Fishpond \\
\hline 13 & $2^{\circ} 30^{\prime} 15.817^{\prime \prime} \mathrm{S}$ & $104^{\circ} 46^{\prime} 23.389^{\prime \prime} \mathrm{E}$ & Open area \\
\hline 14 & $2^{\circ} 21^{\prime} 17.159^{\prime \prime} \mathrm{S}$ & $104^{\circ} 50^{\prime} 30.569^{\prime \prime} \mathrm{E}$ & Open area \\
\hline 15 & $2^{\circ} 20^{\prime} 2.949^{\prime \prime} \mathrm{S}$ & $104^{\circ} 52^{\prime} 41.706^{\prime \prime} \mathrm{E}$ & Open area \\
\hline 16 & $2^{\circ} 16^{\prime} 36.561^{\prime \prime} \mathrm{S}$ & $104^{\circ} 53^{\prime} 59.572^{\prime \prime} \mathrm{E}$ & Water body \\
\hline 17 & $2^{\circ} 17^{\prime} 1.211^{\prime \prime} \mathrm{S}$ & $104^{\circ} 51^{\prime} 59.945^{\prime \prime} \mathrm{E}$ & Water body \\
\hline 18 & $2^{\circ} 17^{\prime} 4.611^{\prime \prime} \mathrm{S}$ & $104^{\circ} 55^{\prime} 2.086^{\prime \prime} \mathrm{E}$ & Water body \\
\hline
\end{tabular}

The results of the analysis of land cover data were then processed with the open-source software LUMENS version 0.1 of 2016 (van Noordwijk et al. 2016; Nguyen et al. 2016; Untari et al. 2018; Do et al. 2020). This software was able to analyze changes in various types of land cover in an area at one time to see carbon stock (carbon density), emissions, and carbon sequestration. The method used is the Stock Difference method, where emissions were calculated as the amount of reduction in carbon stocks due to changes in land cover if the initial carbon stock was higher than the carbon stock after the change in land use.

Land cover data was in the form of raster data from image interpretation, while the carbon stock constant was obtained from secondary data in the form of tabular data on all types of land cover originating from direct field measurements. Conversely, sequestration was calculated as the amount of additional carbon stock due to changes in land cover, where the carbon stock in the initial land use was lower than the carbon stock after the change in land use. The carbon stock for each land cover derived from the multiplication of the area of land cover and the reference data for the carbon density of South Sumatra Province. The underlying assumption of this study from the rate of change in emissions and carbon sequestration was obtained from changes in land cover types that occur in the same area of the unit area (pixel)

\section{RESULTS AND DISCUSSION}

\section{Land cover conditions 2000 and 2020}

The annual land cover in ATPF for 2000 and 2020 is shown in Figure 2. The land cover in the ATPF area can be classified into primary forest, secondary forest, coconut plantation, open area, fishpond and water body. According to Eddy (Eddy et al. 2017), primary forest in this area is dominated by true mangrove stands, such as Nypa fruticans, Rhizophora apiculata, Avicennia alba, Bruguiera cylindrica, Excoecaria agallocha, and Xylocarpus granatum, while secondary forest contains a mixture of shrubs and mangroves.

(a) 2000

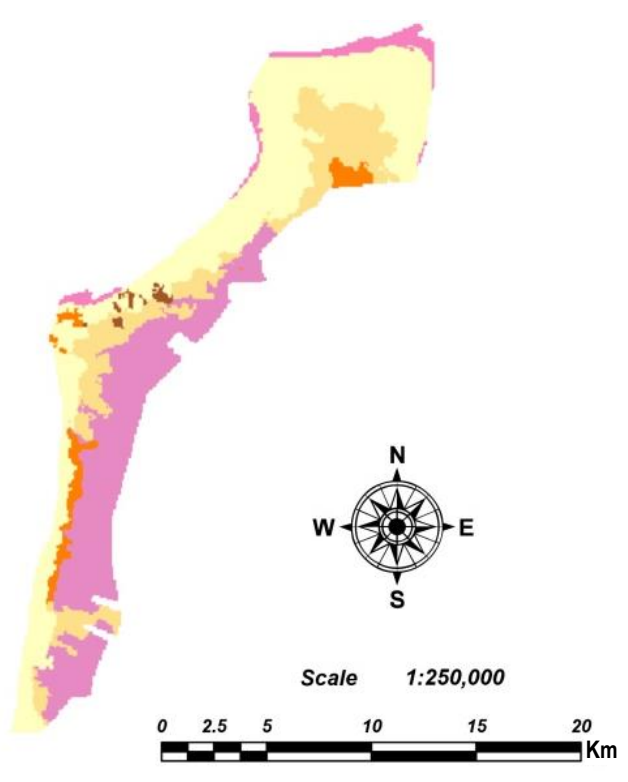

(b) 2020
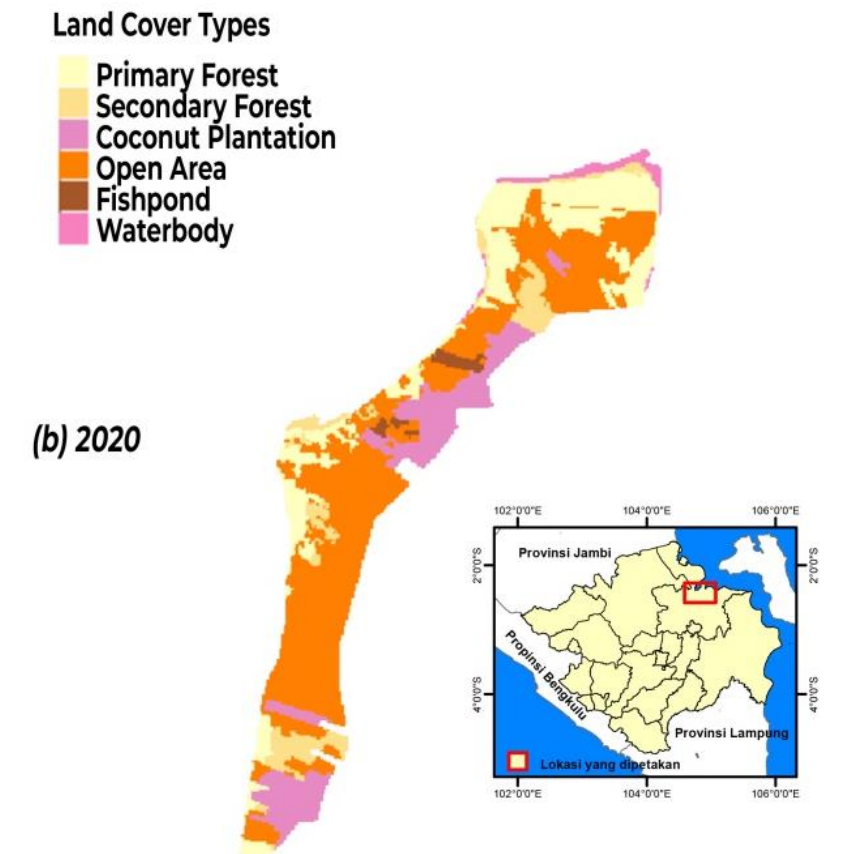

Figure 2. Map of existing land cover types at ATPF 2000 and 2020. The map output is obtained from the analysis using LUMENS 
The land cover in the form of open area in 2020 is an open area but there are also undergrowth and shrubs that dominate this area with an area of up to half of the area of the ATPF. The existence of this open area is due to the clearing of primary and secondary forest for new land by the community and also the area prepared by the community for coconut replanting. Although insignificant, the area of land cover in the form of fishpond was increasing in 2020. The identified coconut plantation area in 2000 was $3,713.43$ ha, but decreased in 2020 to $1,834.56$ ha.

Open areas which are open areas overgrown by undergrowth in the form of shrubs (shrubs) dominate this area in 2020 where the area is half of the area of the ATPF. The existence of this open area is due to the clearing of primary and secondary forest for new land by the community and also the area prepared by the community for coconut replanting. Ponds were identified in 2000 and are increasing in size in 2020 although not significant. The decrease in water body area occurred due to intensive sedimentation at the mouth of the Banyuasin River, causing the formation of new lands. The identified coconut plantation area in 2000 was $3,713.43$ ha, but decreased in 2020 to $1,834.56$ ha.

Table 3. Area of each land cover type in ATPF in 2000 and 2020

\begin{tabular}{lrrrr}
\hline \multirow{2}{*}{ Land cover type } & \multicolumn{2}{c}{$\mathbf{2 0 0 0}$} & \multicolumn{2}{c}{$\mathbf{2 0 2 0}$} \\
& \multicolumn{1}{c}{ ha } & \multicolumn{1}{c}{$\%$} & \multicolumn{1}{c}{ ha } & \multicolumn{1}{c}{$\%$} \\
\hline Primary Forest & $5,321.36$ & 42.03 & $2,936.06$ & 23.19 \\
Secondary Forest & $2,563.83$ & 20.25 & $1,123.02$ & 8.87 \\
Coconut Plantation & $3,713.43$ & 29.33 & $1,834.56$ & 14.49 \\
Open Area & 495.04 & 3.91 & $6,334.23$ & 50.03 \\
Fishpond & 93.69 & 0.74 & 189.91 & 1.50 \\
Waterbody & 473.52 & 3.74 & 243.09 & 1.92 \\
Total & $12,660.87$ & 100.00 & $12,660.87$ & 100.00 \\
\hline
\end{tabular}

\section{Carbon Stock, Emissions and Sequestration 2000-2020}

The condition of carbon stock in ATPF in 2000 and 2020 can be seen in Figure 3. Overall carbon density in 2000 was higher than in 2020. Areas with carbon density in the range of 50-100 ton $\mathrm{CO}_{2}$-eq are still widely distributed, especially in to the north and west in 2000. However, in 2020 the carbon density in this area was dominated in the range of 0-20 tons $\mathrm{CO}_{2}$-eq. This is due to the wider open area opened by the community and the decreasing area of primary and secondary forests.

The emissions generated in ATPF were higher than sequestration during the 2000 and 2020 periods (Figure 4). Almost all regions in the ATPF produced emissions of more than 100 tons $\mathrm{CO}_{2}$-eq, there were even some areas that produced emissions of more than 300 tons $\mathrm{CO}_{2}$-eq in this period. However, the magnitude of emissions is not matched by sequestration. Almost all areas in ATPF did not produce sequestration ( 0 ton $\mathrm{CO}_{2}$-eq), only a few areas produced sequestration in the range above 200 ton $\mathrm{CO}_{2}$-eq. This is due to the rampant clearing of primary and secondary forests by the community to be used as plantation land.

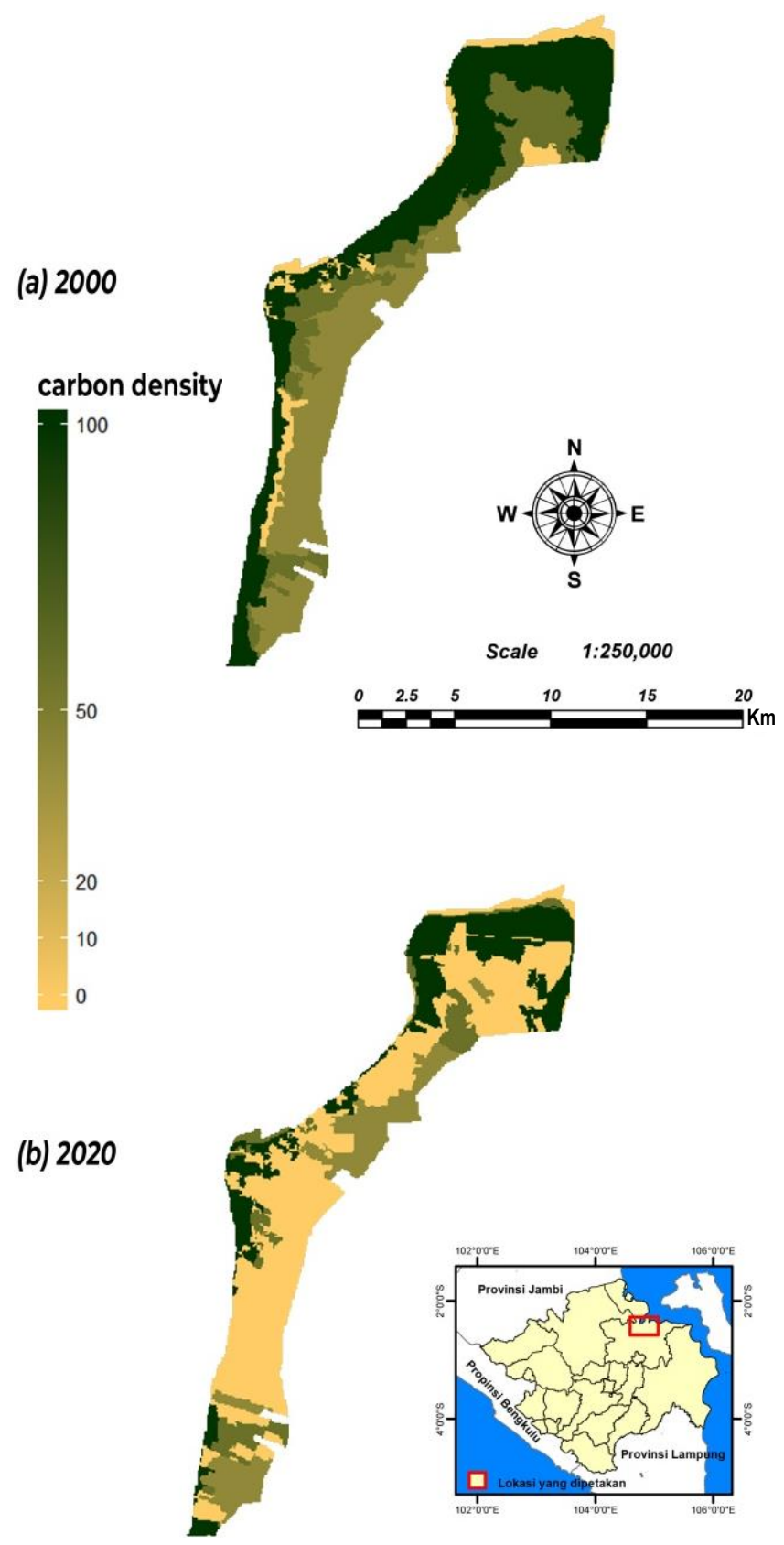

Figure 3. Carbon stock conditions in 2000 and 2020 at ATPF

Emissions resulting from land conversion in ATPF during the 2000-2020 period had a total emission of 1,981,392.08 tons $\mathrm{CO}_{2}$-eq (Table 4). The highest emission resulted from the conversion of primary forest to open areas with an emission level of $873,853.31$ tons $\mathrm{CO}_{2}$-eq or $44.10 \%$ of total emissions. Primary forest is the most important part in nature which has a major role in absorbing carbon. However, with a reduction in the area of primary forest, carbon emissions in nature will increase.

High emissions are also generated from the conversion of coconut plantation into an open area, amounting to $503,865.75$ tons of $\mathrm{CO}_{2}$-eq or around $25.43 \%$ of total emissions. The coconut plantation land that was converted into an open area in 2020 is actually a community effort to rejuvenate old and less productive coconut plants. 
Emissions also resulted from the conversion of secondary forests to open areas, amounting to 372,037.08 tons of $\mathrm{CO}_{2}$-eq or around $18.78 \%$ of total emissions. The clearing of secondary forests is rife by the community to make land for coconut and oil palm plantations. Other sources of

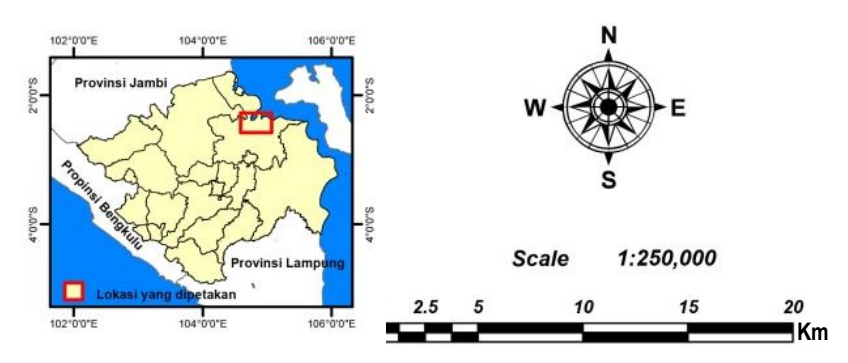

(a) Emission 2000-2020

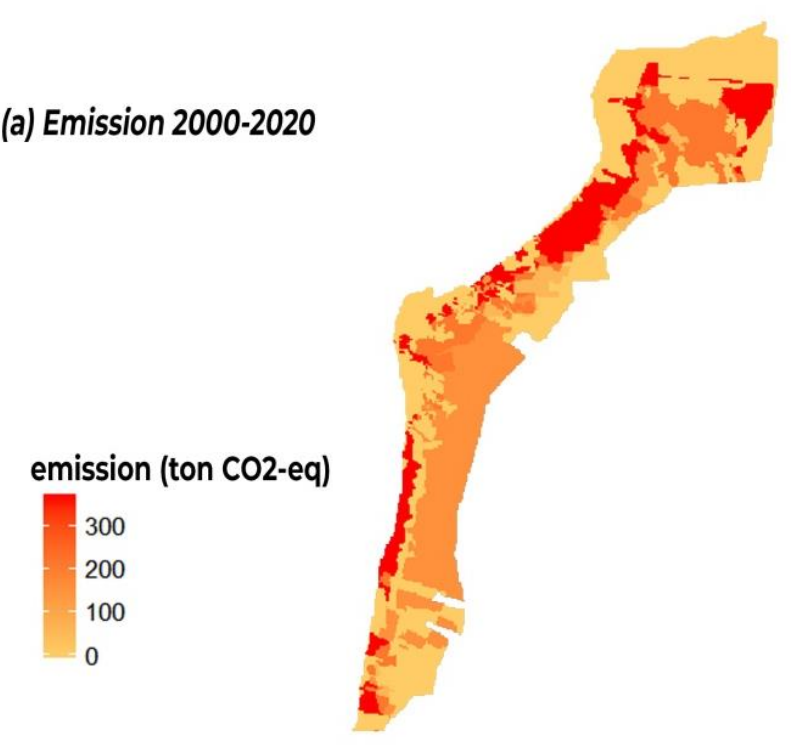

(b) Sequestration $2000-2020$

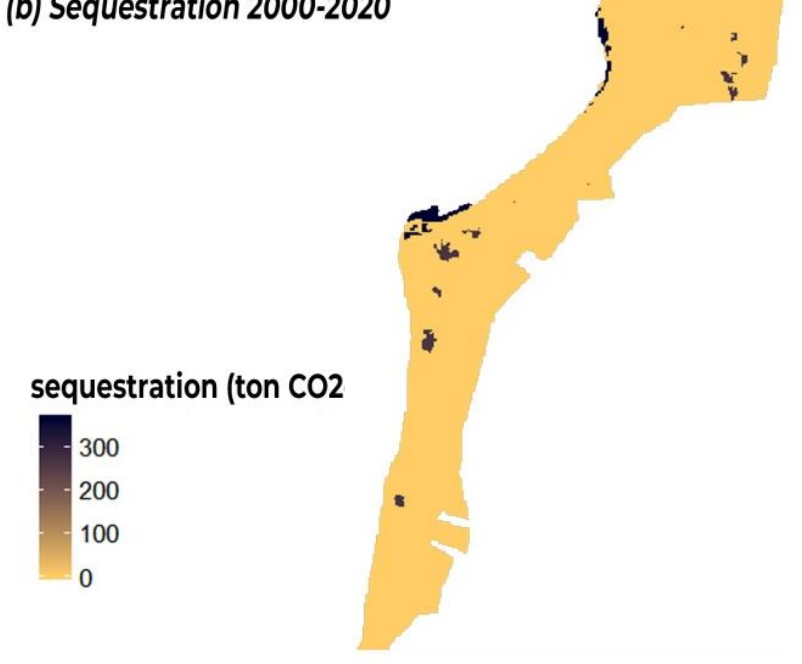

Figure 4. Emissions and sequestration generated during the 20002020 period emissions are also generated from the conversion of primary forest to coconut plantation and fishpond and conversion of primary forest to secondary forest. In addition, emissions are also generated from the conversion of secondary forests to coconut plantations and fishponds.

The total sequestration produced in the ATPF during the 2000-2020 period was far below the total emissions, which was only $53,315.52$ tons $\mathrm{CO}_{2}$-eq or only around $2.7 \%$ of the total emissions (Table 5). This shows that the conversion that has occurred in this area is very massive and has not been matched by revegetation or reclamation processes. The highest sequestration resulted from the conversion of secondary forest to primary forest, amounting to $29,362.35$ tons $\mathrm{CO}_{2}$-eq or more than half of the total sequestration. The change of secondary forest to primary forest is a natural succession process that occurs especially in tidal zones.

Sequestration also occurred due to changes in water bodies to become secondary forests, which amounted to $13,294.58$ tons of $\mathrm{CO}_{2}$-eq or $24.94 \%$ of the total sequestration. This secondary forest was formed as a result of massive sedimentation at the mouth of the Banyuasin River which resulted in the formation of new lands. These new lands are then occupied by mangrove propagules which eventually grow and develop into secondary forests. In addition, sequestration also occurs due to changes in open areas to secondary forest, coconut plantation and primary forest, but the size is not too significant.

Table 6 shows the net emission value generated in ATPF during the 2000-2020 period, which is $1,928,076.56$ tons of $\mathrm{CO}_{2}$-eq (total emission value minus total sequestration value). The annual emission rate is $96,403.83$ tons $\mathrm{CO}_{2}$-eq/year and the average emission rate per unit area is 7.61 tons $\mathrm{CO}_{2}$-eq/ha year.

Table 4. Amount of emissions (tons $\mathrm{CO}_{2}$-eq) resulting from each change in land cover during the $2000-2020$ period

\begin{tabular}{lcc}
\hline \multicolumn{1}{c}{ Land cover changes } & $\begin{array}{c}\text { Emission } \\
\text { (ton COO }\end{array}$ & $\%$ \\
\hline Primary forest to open area & $873,853.31$ & 44.10 \\
Coconut plantation open area & $503,865.75$ & 25.43 \\
Secondary forest to open area & $372,037.08$ & 18.78 \\
Primary forest to coconut plantation & $77,895.42$ & 3.93 \\
Primary forest to secondary forest & $57,807.12$ & 2.92 \\
Primary forest to fishond & $53,501.22$ & 2.70 \\
Secondary forest to coconut plantation & $28,858.09$ & 1.46 \\
Secondary forest to fishpond & $10,340.23$ & 0.52 \\
Coconut plantation to fishpond & $3,233.86$ & 0.16 \\
Total & $1,981,392.08$ & 100.00 \\
\hline
\end{tabular}

Table 5. Quantity of sequestration (tonnes $\mathrm{CO}_{2}$-eq) resulting from each change in land cover during the 2000-2020 period

\begin{tabular}{lrr}
\hline Land cover changes & $\begin{array}{l}\text { Sequestration } \\
\text { (ton } \mathbf{C O}_{2} \text {-eq) }\end{array}$ & \multicolumn{1}{l}{$\%$} \\
\hline Secondary forest to primary forest & $29,362.35$ & 55.07 \\
Waterbody to secondary forest & $13,294.58$ & 24.94 \\
Open area to secondary forest & $6,752.80$ & 12.67 \\
Open area to coconut plantation & $3,541.84$ & 6.64 \\
Open area to primary forest & 363.95 & 0.68 \\
Total & $53,315.52$ & 100.00 \\
\hline
\end{tabular}


Table 6. Statistical data on $\mathrm{CO}_{2}$ emissions and sequestration during the 2000-2020 period

\begin{tabular}{ll}
\hline Category & Summary \\
\hline Total area & $12,660.87$ \\
Total emission (ton $\mathrm{CO}_{2}$-eq) & $1,981,392.08$ \\
Total sequestration $\left(\right.$ ton $\mathrm{CO}_{2}$-eq) & $53,315.52$ \\
Net emission (ton $\mathrm{CO}_{2}$-eq) & $1,928,076.56$ \\
Emission rate (ton $\mathrm{CO}_{2}$-eq/year) & $96,403.83$ \\
Emission rate per-unit area (ton $\mathrm{CO}_{2}$-eq/ha.year) & 7.61 \\
\hline
\end{tabular}

\section{Discussion}

Conversions carried out by the community that occurred in the mangrove forest in ATPF were in the form of changing the mangrove forest to a coconut plantation, fishpond, settlement and agriculture. Anthropogenic activities in the form of land clearing for plantations and agriculture as well as the development of coconut plantation are the dominant activities in this region. This can be seen from the increase in the number of open areas and coconut plantations in 2020, where each area is $6,334.23$ ha and 1,834.56 ha. The open area reaches half of the ATPF area, while the coconut plantation area reaches almost $15 \%$ of the total ATPF area. The large increase in open area and coconut plantation has the consequence of decreasing the area of primary forest and secondary forest. The remaining primary and secondary forests in 2020 are only around $23.19 \%$ and $8.87 \%$ of the total area of ATPF. Anthropogenic disturbances that occur in this area are very massive, so that this area is degraded due to conversion, while reclamation activities have not been maximally carried out. Reclamation was carried out in 2011 by the government and the community, but it only covers a small area so that it is unable to keep up with the speed of degradation due to anthropogenic activities. Various anthropogenic activities in mangrove forests are the main cause of degradation in various regions of the world (Thu and Populus 2007; Donders et al. 2008; Giri et al. 2008, 2014; Ilman et al. 2011; Bryan et al. 2013; Li et al. 2013; Nfotabong-Atheull et al. 2013; Satyanarayana et al. 2013; Jones et al. 2014; Komiyama 2014; Laulikitnont 2014; Sannigrahi et al. 2020).

Emissions that occur in the ATPF region are much greater than sequestration where the magnitude of the emissions is more than 37 times compared to sequestration. The highest emission resulted from the conversion of primary forest to open areas with an emission level of $873,853.31$ ton $\mathrm{CO}_{2}$-eq, while the highest sequestration resulted from the conversion of secondary forest to primary forest, which was only 29,362.35 ton $\mathrm{CO}_{2}$-eq. This indicates that there has been massive degradation in this area due to anthropogenic activities and has not been matched by restoration efforts. To restore the natural function of ATPF as a protected forest, restoration efforts are needed both by the government and the community. However, it is not easy to restore ATPF to its original condition as a protected forest because degraded mangrove forests are not easy to restore in a short time. Development activities in various countries that cause mangrove forest degradation are the main causes of damage and require a restoration time of more than 20 years (Mukherjee et al. 2014). In addition, government support and community participation are needed in an effort to accelerate the success of restoration. The restoration process will be disrupted if there is dysfunction of government institutions and a lack of community participation (Mangora 2011).

The strength of this research is that it can obtain an overall picture of land cover types in ATPF and at the same time can determine the amount of $\mathrm{CO}_{2}$ emission and sequestration and determine the main factors that can increase $\mathrm{CO}_{2}$ emissions. This is very important in an effort to assist the government in regional planning. In addition, it is also useful in planning the mitigation of $\mathrm{CO}_{2}$ emissions in anticipation of global warming. The present work was supported by previous reports how difficult it is to accurately measure the various carbon components even in clearly defined mangrove areas (Serrano et al. 2019; Ouyang and Lee 2020).

In conclusion, emissions resulting from land conversion in ATPF during the 2000-2020 period amounted to 1,981,392.08 tons of $\mathrm{CO}_{2}$-eq $\left(96,403.83\right.$ ton $\mathrm{CO}_{2}$-eq/year). While, sequestration was far below the total emissions, which was only $53,315.52$ tons $\mathrm{CO}_{2}$-eq $(2.7 \%$ of total emissions). The largest source of emissions comes from the conversion of primary forest, coconut plantation and secondary forest to open areas; while the largest source of sequestration is the return of this area to primary and secondary forest. The emission results in ATPF is much greater than the emission produced in one of the mangrove forests of North Sumatra, which is only 3,804.70 ton $\mathrm{CO}_{2-}$ eq/year, where the biggest emission source has resulted from the conversion of secondary mangrove forest to aquaculture and oil palm plantation (Basyuni et al. 2015).

The main source of degradation in ATPF is new land clearing, some of which come from primary and secondary forests, wherein 2020 the open area will reach half of the ATPF area. The result of this situation is massive primary and secondary forest loss. For that, it is necessary to immediately restore and conserve this area in an effort to restore the function of ATPF as a coastal protection forest.

\section{ACKNOWLEDGEMENTS}

Our deepest gratitude goes to Directorate of Research and Community Service, Ministry of Research and Technology and National Research and Innovation Agency, Republic of Indonesia (No. 11/AMD/E1/ KP.PTNB/2020), through the Post-Doctoral Research Scheme 2021.

\section{REFERENCES}

Atwood TB, Connolly RM, Almahasheer H, Carnell PE, Duarte CM, Lewis CJE, Irigoien X, Kelleway JJ, Lavery PS, Macreadie PI, Serrano O, Sanders CJ, Santos I, Steven ADL, Lovelock CE. 2017. Global patterns in mangrove soil carbon stocks and losses. Nat Clim Chang 7 (7): 523-528. DOI: 10.1038/nclimate3326.

Basyuni M, Putri LAP, Murni MB. 2015. Implication of land-use and land-cover change into carbon dioxide emissions in Karang Gading and Langkat Timur Wildlife Reserve, North Sumatra, Indonesia. 
Jurnal Manajemen Hutan Tropika 21 (1): 25-35. DOI: 10.7226/jtfm.21.1.25.

Basyuni M, Putri LAP, Nainggolan B, Sihaloho PE. 2014. Growth and biomass in response to salinity and subsequent fresh water in mangrove seedlings Avicennia marina and Rhizophora stylosa. Jurnal Manajemen Hutan Tropika 20 (1): 17-25. DOI: 10.7226/jtfm.20.1.17.

Basyuni M, Wasilah M, Hasibuan PAZ, Sulistiyono N, Sumardi, S, Bimantara Y, Hayati R, Sagami H, .Oku H. 2019. Salinity and subsequent freshwater influences on the growth, biomass, and polyisoprenoids distribution of Rhizophora apiculata seedlings. Biodiversitas 20 (1): 388-395. DOI: 10.13057/biodiv/d200146.

Bryan JE, Shearman PL, Asner GP, Knapp DE, Aoro G, Lokes B. 2013. Extreme differences in forest degradation in Borneo: comparing practices in Sarawak, Sabah, and Brunei. PLoS ONE 8 (7): e0069679. DOI: 10.1371/journal.pone.0069679.

Do TH, Vu TP, Catacutan D. 2020. Governing Landscapes for Ecosystem Services: A Participatory Land-Use Scenario Development in the Northwest Montane Region of Vietnam. Environ Manag. DOI: 10.1007/s00267-020-01378-2.

Donato DC, Kauffman JB, Murdiyarso D, Kurnianto S, Stidham M, Kanninen M. 2011. Mangroves among the most carbon-rich forests in the tropics. Nat Geosci 4 (5): 293-297. DOI: 10.1038/ngeo1123.

Donders TH, Gorissen PM, Sangiorgi F, Cremer H, Wagner-Cremer F, McGee V. 2008. Three-hundred-year hydrological changes in a subtropical estuary, Rookery Bay (Florida): human impact versus natural variability. Geochem Geophys Geosyst 9 (7): 2008Q07V06. DOI: $10.1029 / 2008 \mathrm{GC} 001980$.

Eddy S, Basyuni M. 2020. Short Communication: The phenomenon of nipah (Nypa fruticans) invasion in the Air Telang Protected Forest, Banyuasin District, South Sumatra, Indonesia. Biodiversitas 21 (11): 5114-5118. DOI: 10.13057/biodiv/d211116.

Eddy S, Iskandar I, Ridho MR, Mulyana A. 2017. Land cover changes in the air telang protected forest, South Sumatra, Indonesia (1989-2013). Biodiversitas 18 (4): 1538-1545. DOI: 10.13057/biodiv/d180432.

Eddy S, Milantara N, Sasmito SD, Kajita T, Basyuni M. 2021. Anthropogenic drivers of mangrove loss and associated carbon emissions in South Sumatra, Indonesia. Forests 12 (2): 187. DOI: 10.3390/f12020187.

Eddy S, Ridho M, Iskandar I, Mulyana A. 2016. Community-based mangrove forests conservation for sustainable fisheries. J Silvikultur Trop 7 (3): S42-S47. DOI: 10.31219/osf.io/x659w.

Eddy S, Ridho MR, Iskandar I, Mulyana A. 2019. Species composition and structure of degraded mangrove vegetation in the Air Telang Protected Forest, South Sumatra, Indonesia. Biodiversitas 20 (8): 2119-2127. DOI: $10.13057 /$ biodiv/d200804.

Ellison AM. 2002. Macroecology of mangroves: large-scale patterns and processes in tropical coastal forests. Trees 16 (2-3): 181-194. DOI: 10.1007/s00468-001-0133-7.

Fatoyinbo TE, Simard M, Washington-Allen RA, Shugart HH. 2008. Landscape-scale extent, height, biomass, and carbon estimation of Mozambique's mangrove, forests with Landsat ETM+ and Shuttle Radar Topography Mission elevation data. J Geophys Res 113: 1-13. DOI: $10.1029 / 2007 J G 000551$.

Feller IC, Lovelock CE, Berger U, McKee KL, Joye SB, Ball MC. 2010. Biocomplexity in mangrove ecosystems. Ann Rev Mar Sci 2: 395 417. DOI: 10.1146/annurev.marine.010908.163809.

Giri C, Long J, Abbas S, Murali RM, Qamer FM, Pengra B, Thau D. 2014. Distribution and dynamics of mangrove forests of South Asia. J Environ Manag 148: 101-111. DOI: 10.1016/j.jenvman.2014.01.020.

Giri C, Zhu Z, Tieszen LL, Singh A, Gillette S, Kelmelis JA. 2008. Mangrove forest distributions and dynamics (1975-2005) of the tsunami-affected region of Asia. J Biogeogr 35: 519-528. DOI: 10.1111/j.1365-2699.2007.01806.x.

Hochard JP, Hamilton S, Barbier EB. 2019. Mangroves shelter coastal economic activity from cyclones. Proc Natl Acad Sci USA 116 (25): 12232-12237. DOI: 10.1073/pnas.1820067116

Ilman M, Wibisono ITC, Suryadiputra INN. 2011. State of the Art Information on Mangrove Ecosystems in Indonesia. State of the Art Information on Mangrove Ecosystems in Indonesia. Wetlands International - Indonesia Programme, Bogor.

Jones TG, Ratsimba HR, Ravaoarinorotsihoarana L, Cripps G, Bey A. 2014. Ecological variability and carbon stock estimates of mangrove ecosystems in Northwestern Madagascar. Forestry 5: 177-205. DOI: 10.3390/f5010177.

Koch EW, Barbier EB, Silliman BR, Reed DJ, Perillo GME, Hacker SD, Granek EF, Primavera JH, Muthiga N, Polasky S, Halpern BS,
Kennedy CJ, Kappel CV, Wolanski E. 2009. Non-linearity in ecosystem services: Temporal and spatial variability in coastal protection. Front Ecol Environ 7 (1): 29-37. DOI: 10.1890/080126.

Komiyama A. 2014. Conservation of mangrove ecosystems through the eyes of a production ecologist. Rev Agric Sci 2: 11-20. DOI: $10.7831 /$ ras.2.11

Kusmana C, Hidayat T, Hikmah WF. 2019. Above-ground biomass and carbon stock of Ciletuh Mangrove Forest, West Java, Indonesia. IOP Conf Ser Earth Environ Sci 394 (1): 012005. DOI: 10.1088/1755$1315 / 394 / 1 / 012005$

Laulikitnont P. 2014. Evaluation of mangrove ecosystem restoration success in Southeast Asia. [Thesis]. University of San Francisco, San Fransisco, CA.

Lee SY, Dunn RJK, Young RA, Connolly RM, Dale PER, Dehayr R, Lemckert CJ, McKinnon S, Powell B, Teasdale PR, Welsh DT. 2006. Impact of urbanization on coastal wetland structure and function. Austral Ecol $31 \quad$ (2): 149-163. DOI: 10.1111/j.14429993.2006.01581.x.

Li MS, Mao LJ, Shen WJ, Liu SQ, Wei AS. 2013. Change and fragmentation trends of Zhanjiang mangrove forests in southern China using multi-temporal Landsat imagery (1977-2010). Estuar Coast Shelf Sci 130: 111-120. DOI: 10.1016/j.ecss.2013.03.023.

Linares AM, López-Portillo J, Hernández-Santana JR, Pérez MO, Orozco OO. 2007. The mangrove communities in the Arroyo Seco deltaic fan, Jalisco, Mexico, and their relation with the geomorphic and physical-geographic zonation. Catena 70 (2): 127-142. DOI: 10.1016/j.catena.2006.05.010.

Mai NTH, Tan NQ, Linh NHK. 2019. Understanding the status and challenges of mangrove conservation in central Vietnam: case study in Duy Xuyen District, Quang Nam Province. Hue Univ J Sci: Agric Rural Dev 128 (3B): 71-83. DOI: 10.26459/hueunijard.v128i3b.5361.

Mangora MM. 2011. Poverty and institutional management stand-off: A restoration and conservation dilemma for mangrove forests of Tanzania. Wetl Ecol Manag 19 (6): 533-543. DOI: 10.1007/s11273011-9234-2.

Mukherjee N, Sutherland WJ, Khan MNI, Berger U, Schmitz N, Dahdouh-Guebas F, Koedam N. 2014. Using expert knowledge and modeling to define mangrove composition, functioning, and threats and estimate time frame for recovery. Ecol Evol 4 (11): 2247-2262. DOI: $10.1002 /$ ece 3.1085.

Murdiyarso D, Purbopuspito J, Kauffman JB, Warren MW, Sasmito SD, Donato DC, Manuri S, Krisnawati H, Taberima S, Kurnianto S. 2015. The potential of Indonesian mangrove forests for global climate change mitigation. Nat Clim Chang 5 (12): 1089-1092. DOI: $10.1038 /$ nclimate2734.

Nagelkerken I, Blaber SJM, Bouillon S, Green P, Haywood M, Kirton LG, Meynecke JO, Pawlik J, Penrose HM, Sasekumar A, Somerfield PJ. 2008. The habitat function of mangroves for terrestrial and marine fauna: A review. Aquat Bot 89 (2): 155-185. DOI: 10.1016/j.aquabot.2007.12.007.

van Noordwijk M, Kim YS, Leimona B, Hairiah K, Fisher LA. 2016. Metrics of water security, adaptive capacity, and agroforestry in Indonesia. Curr Opin Environ Sustain 21: 1-8. DOI: 10.1016/j.cosust.2016.10.004.

Nfotabong-Atheull A, Din N, Dahdouh-Guebas F. 2013. Qualitative and Quantitative Characterization of Mangrove Vegetation Structure and Dynamics in a Peri-urban Setting of Douala (Cameroon): An Approach Using Air-Borne Imagery. Estuar Coast 36: 1181-1192. DOI: 10.1007/s12237-013-9638-8.

Nguyen DT, Iskandar I, Ho S. 2016. Land cover change and the CO2 stock in the Palembang City, Indonesia: A study using remote sensing, GIS technique and LUMENs. Egypt J Remote Sens Space Sci 19 (2): 313-321. DOI: 10.1016/j.ejrs.2016.08.004.

Ouyang X, Lee SY. 2020. Improved estimates on global carbon stock and carbon pools in tidal wetlands. Nature Commun 11 (1): 317. DOI: 10.1038/s41467-019-14120-2.

Ouyang X, Lee SY, Connolly RM, Kainz MJ. 2018. Spatially-explicit valuation of coastal wetlands for cyclone mitigation in Australia and China. Sci Rep 8 (1): 3035. DOI: 10.1038/s41598-018-21217-z.

Sannigrahi S, Zhang Q, Pilla F, Joshi PK, Basu B, Keesstra S, Roy PS, Wang Y, Sutton PC, Chakraborti S, Paul SK, Sen S. 2020. Responses of ecosystem services to natural and anthropogenic forcings: A spatial regression-based assessment in the world's largest mangrove ecosystem. Sci Total Environ 715: 137004. DOI: 10.1016/j.scitotenv.2020.137004. 
Serrano O, Lovelock CE. Atwood TB. et al. 2019. Australian vegetated coastal ecosystems as global hotspots for climate change mitigation Nat Commun 10: 4313. DOI: 10.1038/s41467-019-12176-8.

Satyanarayana B, Mulder S, Jayatissa LP, Dahdouh-Guebas F. 2013. Are the mangroves in the Galle-Unawatuna area (Sri Lanka) at risk? A social-ecological approach involving local stakeholders for a better conservation policy. Ocean Coast Manag 71: 225-237. DOI: 10.1016/j.ocecoaman.2012.10.008.
Thu PM, Populus J. 2007. Status and changes of mangrove forest in Mekong Delta: Case study in Tra Vinh, Vietnam. Estuar Coast Shelf Sci 71: 98-109. DOI: 10.1016/j.ecss.2006.08.007.

Untari, Witdarko, Y, Jefri S. 2018. Analysis of carbon emission level on Merauke Regency land cover. E3S Web Confer 73: 08013. DOI: 10.1051/e3sconf/2018730801. 